\title{
Organotin compounds in surface sediments from seaports on the Gulf of Gdańsk (southern Baltic coast)
}

\author{
Anna Filipkowska • Grażyna Kowalewska • \\ Bruno Pavoni · Leszek Łęczyński
}

Received: 6 October 2010 / Accepted: 25 January 2011 / Published online: 22 February 2011

(C) The Author(s) 2011. This article is published with open access at Springerlink.com

\begin{abstract}
Sediment samples were collected in two Polish ports of international significance-the Port of Gdańsk and the Port of Gdynia (Gulf of Gdańsk, Baltic Sea)-in order to assess their butyltin and phenyltin contamination; this was done in 2008, just after the total ban on using harmful organotins in antifouling paints on ships came into force. Altogether, 21 sampling stations were chosen to present a diversity of port sites: from port canals and shipyards to anchorages and dumping sites. The organic carbon content and grain size of all the sediment samples were determined, and some environmental parameters (oxygen content, salinity) were measured as well. Total concentrations of butyltin compounds in sediment samples were very different and ranged between 1 and 18,520 ng Sn $\mathrm{g}^{-1}$ d.w. Phenyltin
\end{abstract}

A. Filipkowska · G. Kowalewska ( $\varangle)$

Marine Pollution Laboratory, Institute of Oceanology,

Polish Academy of Sciences, ul. Powstańców

Warszawy 55, 81-712 Sopot, Poland

e-mail: Kowalewska@iopan.gda.pl

B. Pavoni

Department of Environmental Sciences,

University of Venice, Calle Larga S. Marta 2137,

30123 Venice, Italy

L. Łęczyński

Department of Marine Geology,

Institute of Oceanography, University of Gdańsk,

Al. M. Piłsudskiego 46, 81-378 Gdynia, Poland contents were distinctly lower and ranged from below the limit of detection (most samples) to $660 \mathrm{ng} \mathrm{Sn} \mathrm{g}^{-1} \mathrm{~d}$.w. The highest concentrations of organotins were found in the shipyards, the maximum total organotin content (19,180 $\mathrm{ng} \mathrm{Sn}^{-1}$ d.w.) being found in the Gdańsk Ship Repair Yard 'Remontowa'. Butyltin degradation indices indicate a recent tributyltin input into the port sediments. The results obtained from this work prove that the international ban on using organotins may not be enough to protect the marine environment. It is necessary to monitor organotin contamination in ports and establish concentration limits of these compounds for the disposal of dredged material at sea.

Keywords Tributyltin • Organotins • Sediment • Port • Baltic Sea

\section{Introduction}

Organotin compounds (OTs), due to their special properties, have been widely utilized in the industry as PVC stabilizers and catalysts, in agriculture as biocides and also as antifouling agents in paints used to prevent the settlement and growth of aquatic organisms on ship hulls, fish cages, oil rig supports, etc. During the last 60 years, considerable amounts of organotins have entered various ecosystems (Hoch 2001). Tributyltin (TBT) and 
triphenyltin are the compounds of this group most often discharged into the marine environment. These compounds exhibit biocidal properties and have been used as active ingredients in marine antifouling coatings. Since the first toxic effects of OTs to aquatic life were discovered at the end of the 1970s (Alzieu 1998; Champ 2000), they still arouse interest and give cause for concern. Tributyltin causes chronic and acute poisoning of the most sensitive aquatic organisms, such as algae, zooplankton, molluscs and the larval stages of some fish species. Triphenyltin is less toxic to marine species than tributyltin but nonetheless poses a hazard to aquatic life (Hoch 2001). Both tributyltin and triphenyltin are recognized as the one of the most hazardous substances that have deliberately been released into the marine environment (HELCOM 2010). Organotin compounds decompose rapidly in seawater but tend to adsorb on particles and aggregates in sediments, where degradation processes are considerably slower and may last for years (Evans 1999; Hoch 2001; Maguire 1987). They are still bioavailable as a result of their resuspension, diffusion into the water column or decomposition (Díez et al. 2002).

In the 1980s and the 1990s, many countries included in their legislation a number of restrictions on the use of tributyltin-based antifouling paints, and then the International Maritime Organization (IMO) introduced a 10-year period to implement a complete ban known as the AFS Convention: 1 January 2003 was the last date for the application of these paints and 1 January 2008 the last date for tributyltin-based marine coatings to be left on a vessel (IMO 2001). The Convention entered into force on 17 September 2008. However, according to EC Regulation 782/2003 (EU 2003), all EU flagged ships and also EU ports had to comply with the AFS Convention requirements starting from July 2003. Poland as a member of the European Union implemented this regulation by Dz.U.06.99.692 (PL Reg. 2006). It is worth noting that the evolution of TBT bans is quite complex, and multiple levels and areas of legislation (international and national) still present problems (Champ 2000; Gipperth 2009). Since the IMO ban came into force, sediments from ports, harbours and shipyards instead of vessels became a significant source of tributyl- and triphenyltin for aquatic life. The risk of OT remobilization from sediments to the water phase is particularly high during the dredging and disposal of contaminated sediments at sea. The recent HELCOM (Baltic Marine Environment Protection Commission) report on hazardous substances of specific concern to the Baltic Sea (HELCOM 2009) puts tributyltin and triphenyltin at the top of the list of compounds that should be monitored in the Baltic environment and draws attention to the lack of data on these compounds.

There are a lot of studies concerning the presence and harmfulness of OTs in the marine environment, but only few of these relate to Baltic sediments (e.g. Biselli et al. 2000; Eklund et al. 2010; Strand et al. 2003) including the Gulf of Gdańsk (southern Baltic Sea, Poland; e.g. Falandysz et al. 2002, 2006; Radke et al. 2008a; Senthilkumar et al. 1999; Szpunar et al. 1997). Moreover, most of them are based on results for samples collected before 2003, i.e. before the year when the partial ban on organotins was introduced.

The aim of this work was to assess organotin contamination (tributyltin, triphenyltin and their derivatives) in sediments collected in 2008, in two Polish ports of international significance (Gdańsk and Gdynia) located on the coast of the Gulf of Gdańsk (Baltic Sea). The extent of contamination of the port sediments immediately after the implementation of the total ban on using harmful organotins in antifouling paints on ships' hulls will be a particularly valuable point of reference for assessing the effectiveness of the regulation in this region.

\section{Material and methods}

Sample collection

The Port of Gdańsk is a major international seaport located in the central part of the southern Baltic coast (Poland). According to EU strategy, the Port of Gdańsk plays a significant role as a key link in Trans-European Transport Corridor No. 6 connecting the Nordic countries with southern and eastern Europe. The Port of Gdańsk's total 
area is $10.65 \mathrm{~km}^{2}$ (land and water) and the total length of its quays is more than $21 \mathrm{~km}$. It consists of two main sections: the Inner Port stretching along the Dead Vistula River and the Port Canal, and the Northern Port, which opens directly to the Gulf of Gdańsk. There are also active shipyards, namely, the Gdańsk Shipyard and the Gdańsk Ship Repair Yard 'Remontowa'. The latter is a leading European ship repair yard and a major player in the world market.

The Port of Gdynia is another Baltic seaport located on the western coast of the Gulf of Gdańsk. This port is smaller but still covering a total area of $7.55 \mathrm{~km}^{2}$ and having a total quayside length of $17.7 \mathrm{~km}$. Active shipyards are the Ship Repair Yard 'Nauta', the Naval Shipyard and the Gdynia Shipyard.

Sediment samples $(0-5 \mathrm{~cm})$ were collected in November 2008 with a van Veen grab in both ports and at dumping sites for materials dredged from these ports. The locations of the sampling stations are shown on the map (Fig. 1), and the characteristics of the stations are given in Table 2. Stations P1-P7 are located in the Port of Gdańsk, stations P12-P17 in the Port of Gdynia. Stations P8-P9 and P18 are, respectively, located in the Gdańsk and Gdynia anchorages, whereas the dumping sites are represented by stations P10 P11 (Gdańsk) and P19-P21 (Gdynia). Altogether 21 sediment samples were collected and stored at $-20^{\circ} \mathrm{C}$. The content of organotin compounds and organic carbon and also sediment grain size were determined in sub-samples. The salinity and oxygen content in the seawater were measured at each sampling station using a portable field meter (ProfiLine Multi 197i; WTW, Germany).

\section{Organotin determinations}

The following six OTs were quantified in the sediment samples: TBT, dibutyltin (DBT), monobutyltin (MBT), triphenyltin (TPhT), diphenyltin

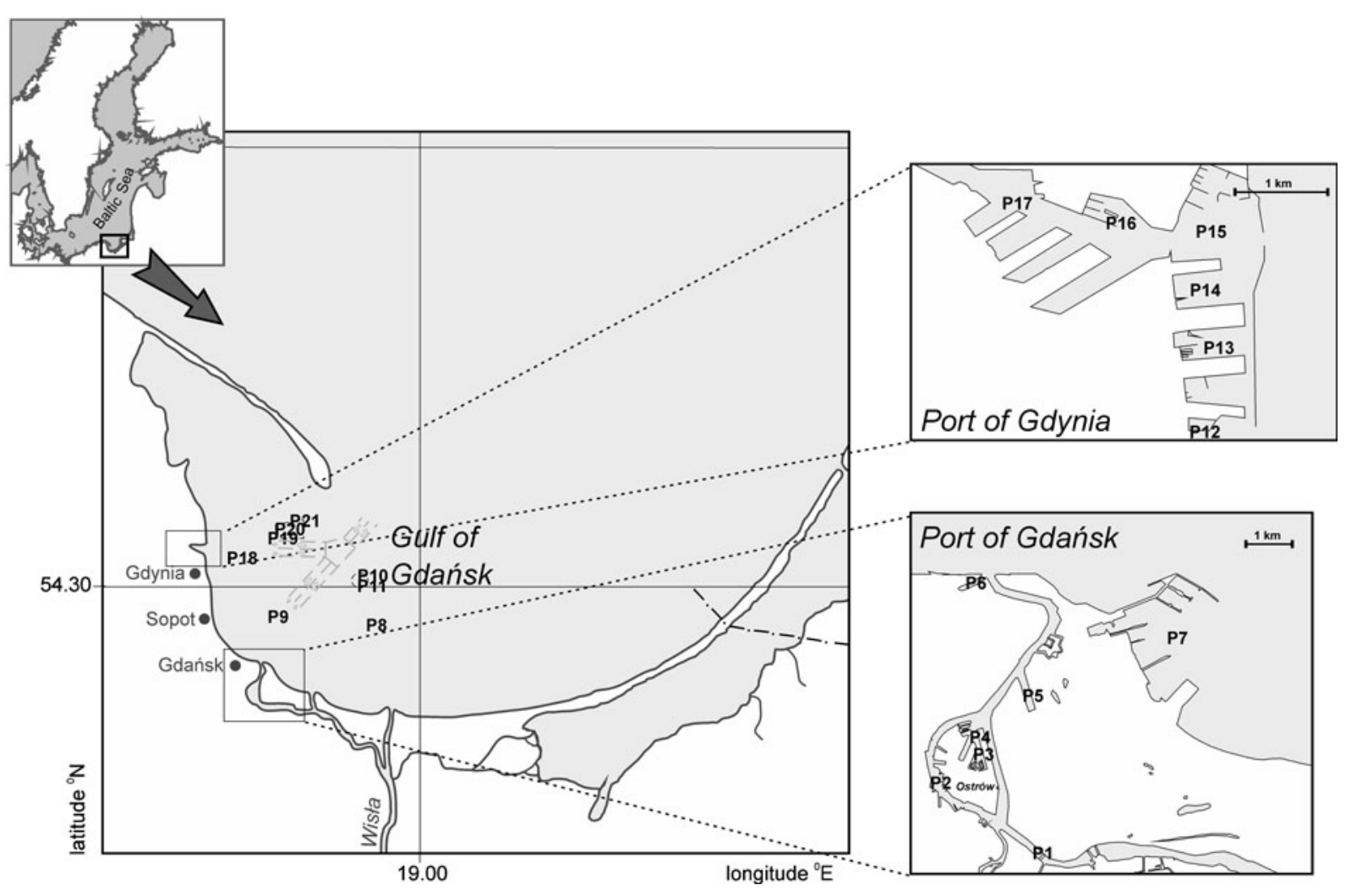

Fig. 1 Location of the sampling stations 
$(\mathrm{DPhT})$ and monophenyltin (MPhT). Organotin compounds were extracted, cleaned up and quantified according to the procedure described by Bortoli et al. (2003) and Pellizzato et al. (2004). A diagram of the analytical procedure is presented in Fig. 2. In brief, freeze-dried, homogenized sediment samples (0.5-1.6 g) were triply

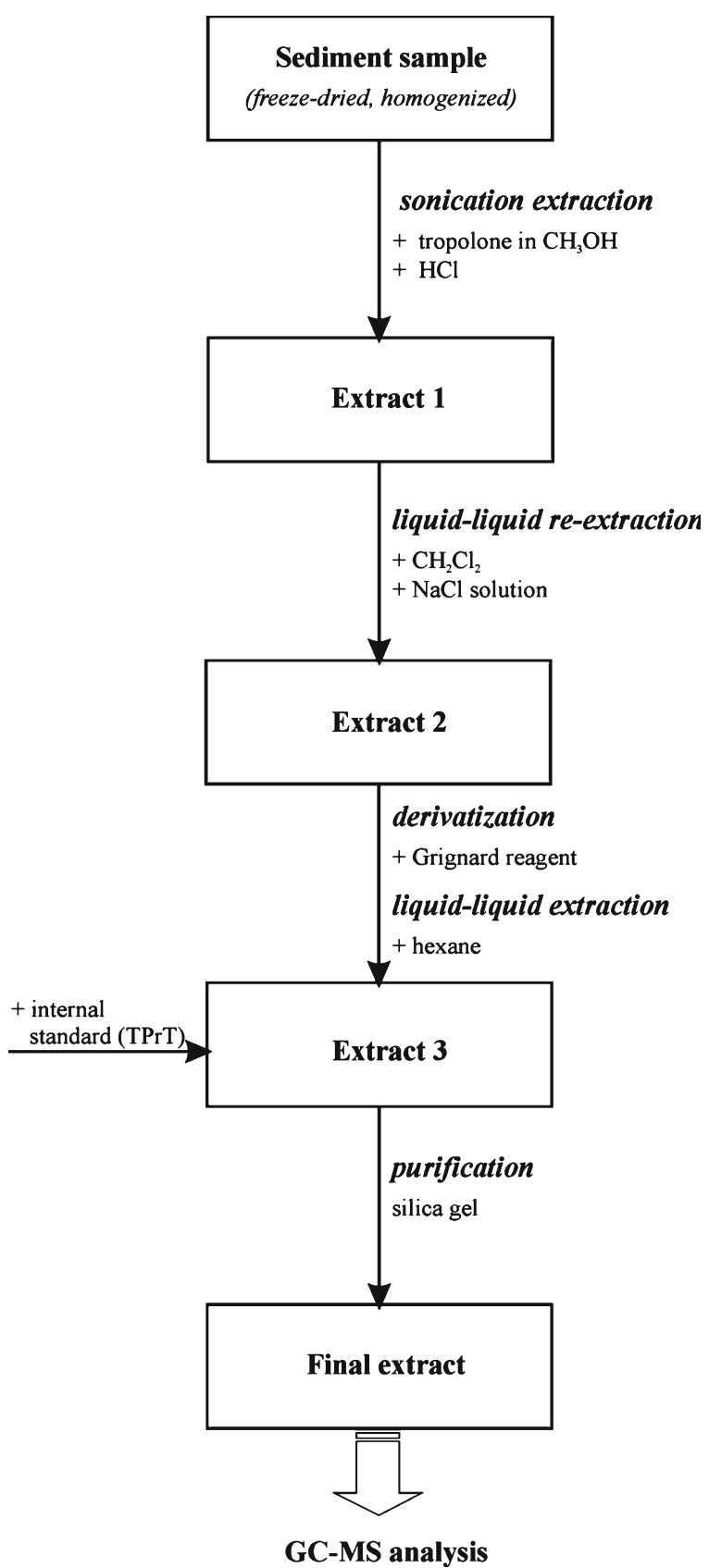

Fig. 2 Diagram of the analytical procedure sonication-extracted in a test tube with $7 \mathrm{~mL}$ methanol solution of tropolone $(0.03 \%)$ and $0.7 \mathrm{~mL}$ of $\mathrm{HCl}(37 \%)$ and centrifuged for $20 \mathrm{~min}$ at 3,500 rpm. Extracts were then twice liquidliquid partitioned in a separatory funnel with $15 \mathrm{~mL}$ dichloromethane. One hundred millilitres of $10 \% \mathrm{NaCl}$ in deionized water were added to enhance separation of phases. The organic phase was then dewatered completely by elution in a short column of activated $\mathrm{Na}_{2} \mathrm{SO}_{4}$. After washing the $\mathrm{Na}_{2} \mathrm{SO}_{4}$ with $2 \mathrm{~mL}$ of $\mathrm{CH}_{2} \mathrm{Cl}_{2}, 1 \mathrm{~mL}$ of isooctane was added. After the volume of the extract was reduced in a gentle stream of argon, derivatization with a Grignard reagent $(2.0 \mathrm{M}$ pentylmagnesium chloride solution in tetrahydrofuran) was carried out. The derivatized OTs were extracted in a test tube with $n$-hexane and $1 \mathrm{M}$ $\mathrm{H}_{2} \mathrm{SO}_{4}$ solution, after which the internal standard (tripropylpentyltin (TPrT)) was added. The organic phase was reduced under a gentle stream of argon and purified on a column containing activated silica gel soaked with a mixture of $n$-hexane and toluene $(1: 1(v / v))$. Organotin compounds were eluted with the same solution. The extract obtained was evaporated to $1 \mathrm{~mL}$ and analysed using a gas chromatograph (Varian 3900 GC, USA) coupled to a mass spectrometric detector (Saturn 2100T GC/MS, Varian). A capillary column (Varian VF-5 ms-0.20 mm ID $\times 50 \mathrm{~m}$, $0.33 \mu \mathrm{m}$ film thickness) containing a $5 \%$ phenyl + 95\% dimethylpolysiloxane stationary phase was used. The carrier gas was helium (column flow$0.8 \mathrm{~mL} / \mathrm{min}$ ), and the sample was injected in splitless mode; after $2 \mathrm{~min}$, the split mode was switched on. OTs were detected by a mass spectrometer equipped with an ion trap using a Selected Ion Storage Acquisition Programme under electron impact ionization. The following chromatographic conditions were applied: injector temperature $300^{\circ} \mathrm{C}$, ion trap temperature $210^{\circ} \mathrm{C}$, manifold temperature $50^{\circ} \mathrm{C}$, transfer line temperature $280^{\circ} \mathrm{C}$. The oven temperature programme was held isothermally at $80^{\circ} \mathrm{C}$ for $2 \mathrm{~min}$ then programmed at $10^{\circ} \mathrm{C} \mathrm{m^{-1 }}$ to $290^{\circ} \mathrm{C}$ and held for $20 \mathrm{~min}$. Determination of OT concentrations were based on the response factors derived from daily repeated injections of a standard mixture of derivatized compounds. The ion masses used to identify organotin compounds were the following: TPrT (internal 
standard) -277, 275, 273; TBT-305, 303, 301; DBT and MBT-319, 317, 315; MPhT-339, 337, 335; DPhT_345, 343, 341; TPhT-351, 349, 347. All samples were analysed in duplicate, and for each sample, a duplicate blank was analysed.

Validation of the procedure was based on the intercalibration between two laboratories (Table 1): Department of Environmental Sciences, University of Venice, where the procedure was worked out and verified using the reference material CRM 477 (Bortoli et al. 2003; Pellizzato et al. 2004) and Marine Pollution Laboratory, Institute of Oceanology, Polish Academy of Sciences. The Student's $t$ test applied to differences between the mean values gave positive results $(p<0.05)$ for TBT and DBT $(18 \%$ and $14 \%$, respectively). Basing on comparisons with preceding intercalibration exercises, the results were considered satisfactory.

\section{Other analyses}

The organic carbon concentration in the sediments was determined by wet chromic acid titration (Gaudette et al. 1974). Comparison of the results using this method with those obtained with an automatic organic carbon analyser indicated discrepancies not exceeding $1 \%$ of the measured value.

The grain size characteristics of the sediments were determined according to the method described by van Reeuwijk (2002). The dry sieve analysis was supplemented with pipette analysis in the case of samples in which grains $<0.0625 \mathrm{~mm}$ in diameter were estimated to be more than $10 \%$ and their weight was more than $3 \mathrm{~g}$ (Myślińska 1998).

\section{Statistical analysis}

The results were statistically analysed using STATISTICA 6.0 software (Statsoft, Poland).
The conditions necessary for using parametric tests were routinely checked. The normal distribution of the characteristics in each group was tested with the Shapiro-Wilk test. The following statistical methods were applied: correlation analysis, principal component analysis (PCA) and cluster analysis. Correlation analysis was used to evaluate the relationships between the organotin content in the sediment and organic carbon content, grain size and environmental parameters. Due to the basic conditions necessary for using the R-Pearson parametric linear correlation were not fulfilled, its non-parametric equivalent-the R-Spearman correlation-was applied to the dataset. A correlation with $p<0.01$ was regarded as significant. Relationships between the content of organotin compounds in the sediment samples and other measured parameters were also checked using PCA. Cluster analysis (Ward's method, Euclidean distance) was used to sort sampling stations into groups with similar organotin contamination.

\section{Results and discussion}

Concentrations of organotin compounds

The sediment samples collected in the Ports of Gdańsk and Gdynia in November 2008 were highly contaminated with OTs, mainly with TBT and its degradation products (DBT and MBT) (Table 2). In most of the samples, phenyltin derivatives were below the limit of detection (LOD). In the few cases in which TPhT and MPhT were determined (DPhT $<$ LOD in all the samples), the percentage of these compounds in the sum of six OTs was low and did not exceed 3.5\%. Concentrations of $\Sigma 6$ OTs in the samples ranged between 1 and 19,180 ng $\mathrm{Sn}^{-1}$ d.w. The highest contents of organotin compounds were determined at station P3 located in the Gdańsk Ship Repair

Table 1 Results of laboratory intercalibration [ng Sn $\mathrm{g}^{-1}$ d.w.]

\begin{tabular}{llllrlll}
\hline Sediment sample_P17 & TBT & DBT & MBT & MPhT & DPhT & TPhT & $\Sigma$ OTs \\
\hline MPL, IO-PAS $n=2$ & $1,910 \pm 70^{a}$ & $391 \pm 13$ & $165 \pm 26$ & $14 \pm 2$ & $<7$ & $7 \pm 1$ & $2,490 \pm 110$ \\
DES, UNIVE $n=2$ & $1,570 \pm 20$ & $455 \pm 4$ & $207 \pm 6$ & $7 \pm 3$ & $<12$ & $<3$ & $2,240 \pm 10$ \\
\hline
\end{tabular}

$M P L, I O-P A S$ Marine Pollution Laboratory, Institute of Oceanology, Polish Academy of Sciences; DES, UNIVE Department of Environmental Sciences, University of Venice

${ }^{a}$ Mean value $\pm R / 2\left(R=\left|x_{1}-x_{2}\right|\right)$ 


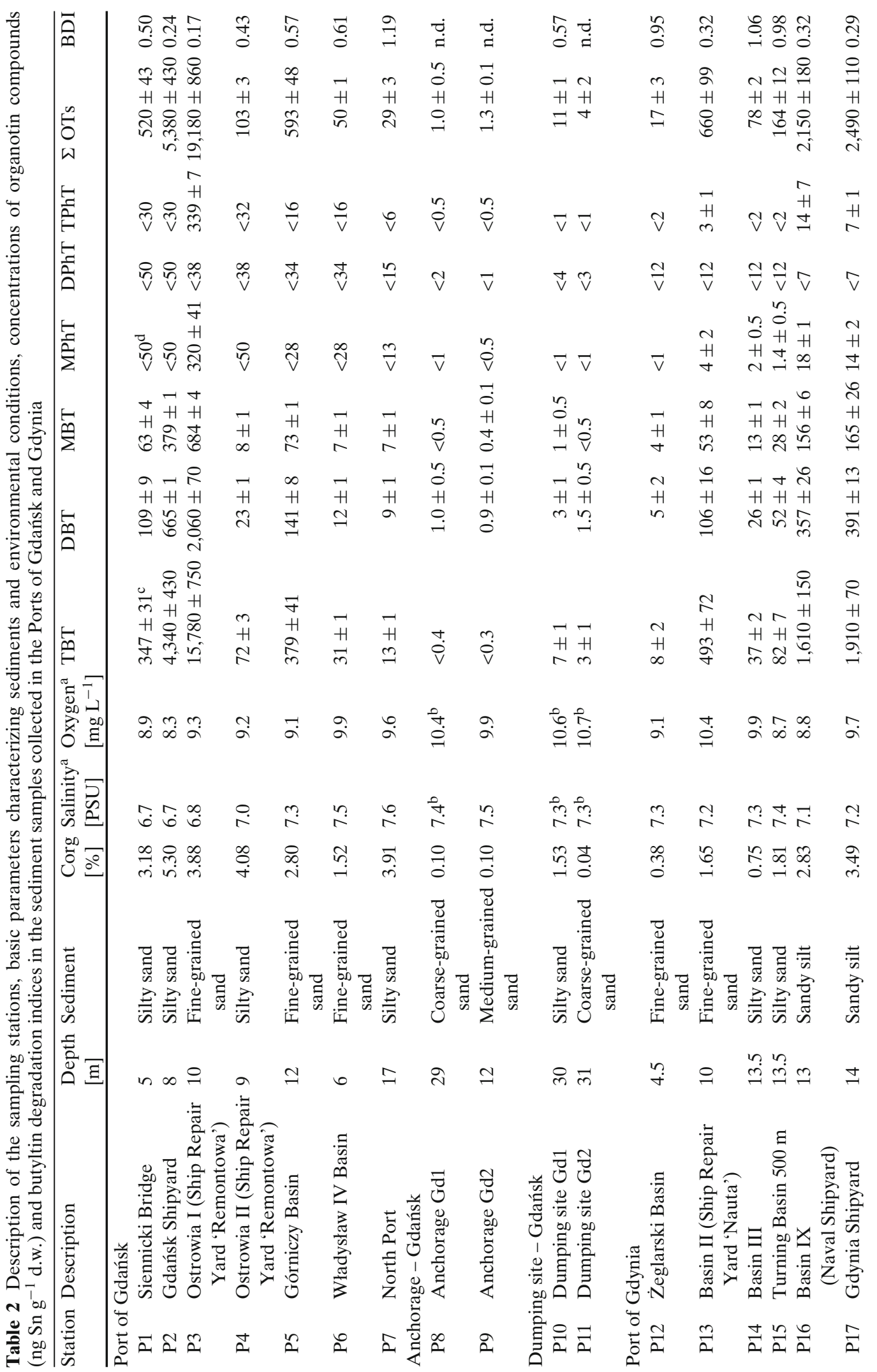


Yard 'Remontowa'. Compared to the rest of the samples it seems that station P3 is an extreme case. Substantial OT pollution was also recorded in the other shipyards, i.e. at station P2 (5,380 ng Sn $\mathrm{g}^{-1}$ d.w.) and at two stations in the Port of Gdynia: P16 and P17 (2,150 and 2,490 ng Sn $\mathrm{g}^{-1}$ d.w., respectively). Other sampling stations with considerable concentrations of total OTs were P1 (520 ng Sn g ${ }^{-1}$ d.w.), P5 (593 ng Sn g ${ }^{-1}$ d.w.) and P13 (660 ng Sn $g^{-1}$ d.w.). There is also a small group of samples where organotin contents ranged between 100 and 164 ng Sn g ${ }^{-1}$ d.w. (P4, P15, P20). In other sediment samples (half of all the samples), the sum of organotins did not exceed $78 \mathrm{ng} \mathrm{Sn} \mathrm{g}^{-1}$ d.w. Organotin pollution was least in the sediments from the anchorages and dumping site belonging to the Port of Gdańsk (1-11 ng Sn $\mathrm{g}^{-1}$ d.w.; P8-P11). For comparison, concentrations of $\Sigma 6$ OTs in the sediment samples collected from the Gdynia anchorage and dumping site ranged between 14 and $120 \mathrm{ng} \mathrm{Sn} \mathrm{g^{-1 }}$ d.w. (P18-P21). These observations are confirmed by hierarchical clustering analysis. Figure 3 a shows the dendrogram of sampling stations where one main cluster (B) and a single observation (A) can be identified. Station P3 (observation A) is an exceptional case. Cluster B consists of two other sub-clusters: B1 and B2. In general, the shipyard stations are grouped in cluster B1, while cluster B2 contains the remaining stations.

The sediment organotin concentrations determined in the Ports of Gdańsk and Gdynia are similar to or higher than those presented by Falandysz et al. (2006) for the Port of Gdynia (Ship Repair Yard 'Nauta'-total BTs: 640 ng Sn g ${ }^{-1}$ d.w.,

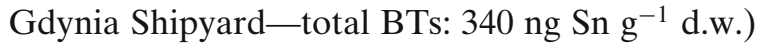
and by Radke et al. (2008a) for the Port of Gdańsk (total BTs 164-9,340 ng Sn g ${ }^{-1}$ d.w., total PhTs: max. $84 \mathrm{ng} \mathrm{Sn} \mathrm{g}^{-1}$ d.w., in $<2.00 \mathrm{~mm}$ sediment fraction). However, the results are lower than those reported by Senthilkumar et al. (1999) for the Port of Gdańsk (total BTs 2,900-69,100 ng Sn $\mathrm{g}^{-1}$ d.w.), by Szpunar et al. (1997) for the Port of Gdynia (total BTs 1,300-5,520 ng Sn g ${ }^{-1}$ d.w.) and by Falandysz et al. (2006) for the Gdańsk seaport (total BTs 170-30,000 ng Sn $g^{-1}$ d.w.). All the quoted results refer to samples collected between 1993 and 2005, i.e. before the total ban on the use of organotins was introduced. Nevertheless, 
a

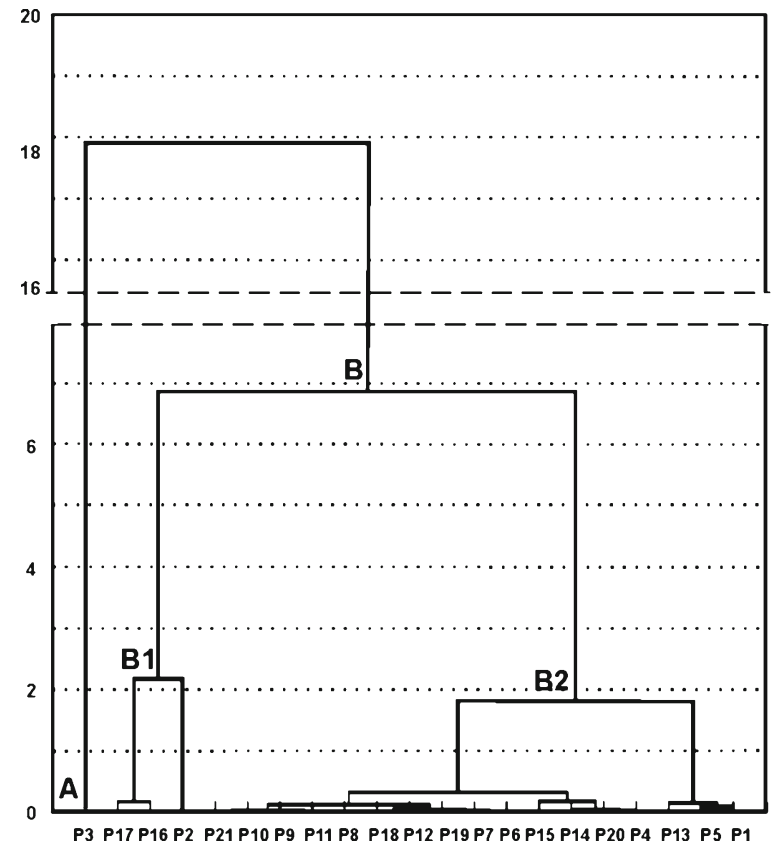

b

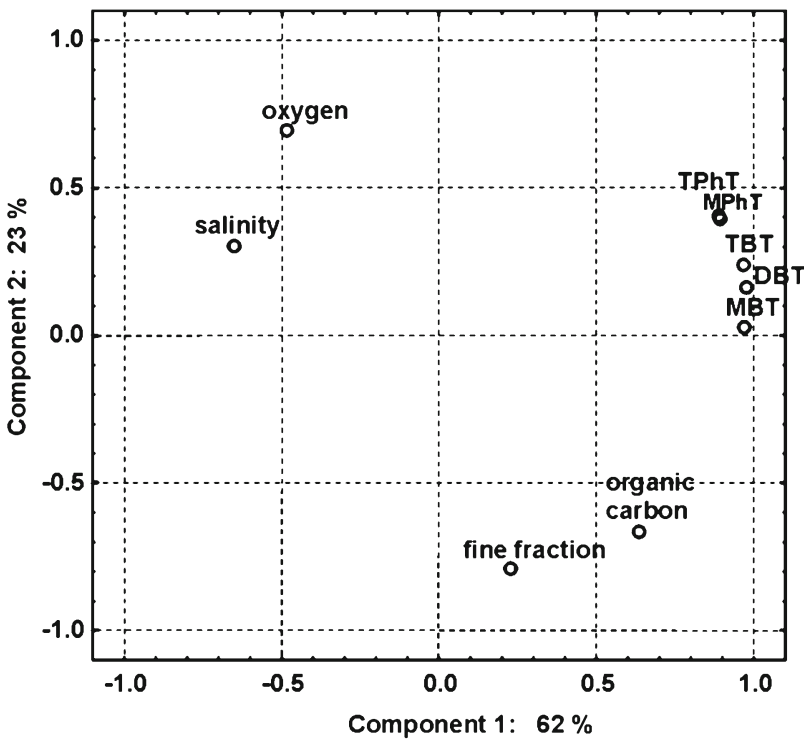

Fig. 3 Results of statistical analysis: a hierarchical dendrogram of sampling stations (cluster analysis: Ward's method, Euclidean distance), b scatterplot of principal component loadings by individual variables

it is worth noting that the highest contents of butyltins have always been recorded close to Ostrów Island, where the Gdańsk Ship Repair Yard

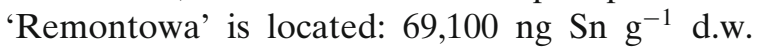
(Senthilkumar et al. 1999), 30,000 ng Sn g ${ }^{-1}$ d.w. (Falandysz et al. 2006), 9,340 (Radke et al. 2008a), $18,520 \mathrm{ng} \mathrm{Sn}^{-1}$ d.w. (this work), whereas the Port of Gdynia was found to be less contaminated with these compounds than the Port of Gdańsk. The available data of BT pollution in Polish ports are presented in Fig. 4. Even though the comparison is difficult, as the stations previously monitored are close, but not superimposing to ours and analytical procedures are in part different, an interpretable time trend of butyltin concentrations in sediments is observed in the recent years: a general decrease due to restrictions is followed by an increase in 2008 . This was probably related to wastes containing antifouling coatings removed from ships. Trends for phenyltin compounds were not included due to the lack of published data. Regardless of trends the concentration of organotins in sediments of both ports still give cause for concern.
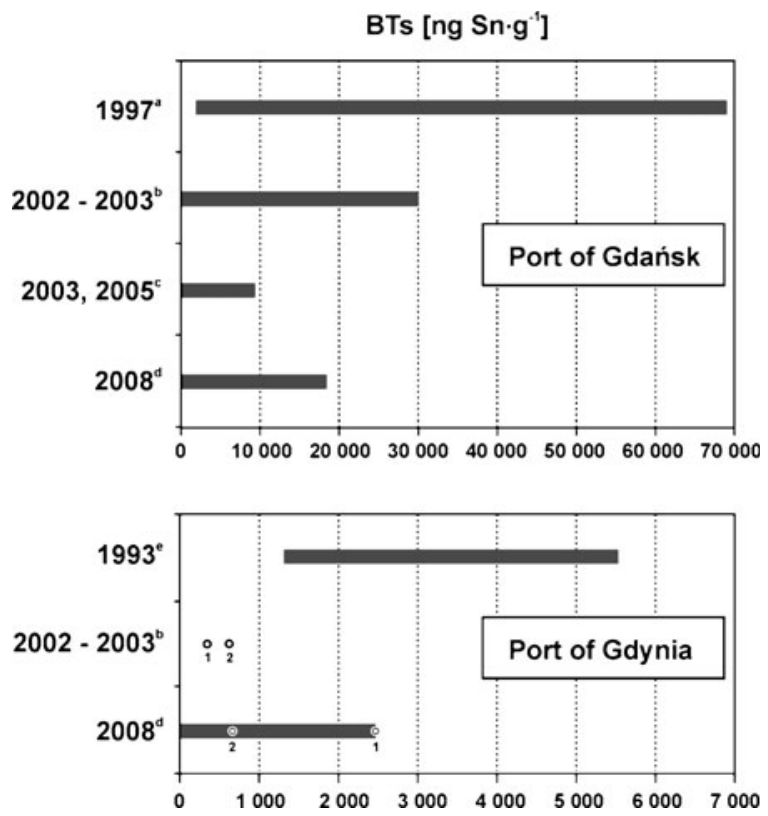

Fig. 4 The available data of BT pollution in the Port of Gdańsk and the Port of Gdynia ( $a$ Senthilkumar et al. (1999); $b$ Falandysz et al. (2006); $c$ Radke et al. (2008a); $d$ this work; $e$ Szpunar et al. (1997); 1 Gdynia Shipyard; 2 Ship Repair Yard 'Nauta') 
Degradation index of organotin compounds

Many factors are responsible for OT degradation in the marine environment and it is not easy to assess how recent the input is. However, the most commonly used index is the ratio between TBT and its breakdown products (butyltin degradation index (BDI)) (Díez et al. 2002). Taking into account that the samples were collected at the same time, in a relatively small area and under similar environmental conditions (Table 2), the use of BDI seems to be appropriate. Its values for the samples are shown in Table 2. As BDI values are less than 1 for the vast majority of the samples, it can be stated that the TBT input into the port sediments, both in Gdańsk and in Gdynia, is recent. The lowest BDI, determined for station P3 (0.17), has a special significance and shows again that this is an extreme case among the samples. It is also worth noting that low BDI values $(<0.5)$ were determined for all the samples collected from the shipyards (in Gdańsk: P2-Gdańsk Shipyard, P3 and P4-Gdańsk Ship Repair Yard 'Remontowa'; in Gdynia: P13 - Ship Repair Yard 'Nauta', P16Naval Shipyard and P17-Gdynia Shipyard). The BDI is slightly higher than one only for two stations-P7 and P14 - indicating an older contamination at these stations. The phenyltin degradation index was not determined for all samples because the phenyltin contents were below the LOD in the vast majority of the samples. Nevertheless, in the cases where TPhT and MPhT were determined $(\mathrm{TPhT}<\mathrm{MPhT}$ for all the stations, except for P3), and remembering that there were only a few samples containing phenyltin compounds, it would appear that TPhT is no longer used in these two ports. In this respect, too, station P3 is exceptional in comparison with the other samples.

\section{Correlations between variables}

Statistically significant correlation coefficients $(p<0.01)$ between concentrations of individual organotins were found-from 0.59 (TPhT-MBT, TPhT-DBT) to 0.99 (TBT-DBT, MBT-DBT). In general, the highest correlations were observed between butyltin compounds $(0.99,0.98)$. This agrees with the results obtained in the Port of
Gdańsk by Radke et al. (2008a) and is explained as the effect of similar accumulation pathways and degradation processes in sediments or similar sources of organotins in this environment.

As a study area, seaports are quite special, and the seeking of distinctive relationships between the OT content and environmental parameters has turned out to be pointless in this case, especially if we consider that both salinity and oxygen content did not change in this area. Nevertheless, the results of principal component analysis (Fig. 3b) generally is in agreement with the existing knowledge of the impact of aerobic conditions or salinity on the fate of organotins in the environment (Hoch 2001; Maguire 1987; Radke et al. 2008b). The PCA data matrix model explains $85 \%$ of the total variation with the first two principal components. The first of them $(62 \%$ of the total variance) points out a compact group of OTs, thus confirming a high, positive correlation between these compounds. The negative, quite high loadings of oxygen content and salinity indicate that as the values of these parameters increase, the organotin content decreases. The high positive correlation coefficient between the butyltin degradation index and seawater salinity $(0.7 ; p<0.01)$ also demonstrate that relationship. The second principal component ( $23 \%$ of the total variance) groups together two other variables: the organic carbon content and the fine fraction of sediment (grain diameter $<0.0625 \mathrm{~mm}$ ). This is in agreement with the correlation coefficients obtained between butyltins and the organic carbon content (0.74-0.77, $p<0.01)$ and between butyltins and the fine fraction of sediment $(0.59-0.64, p<0.01)$. These results correspond also to the conclusions presented by e.g. Berg et al. (2001), Burton et al. (2004), Fent (1996) or Hoch and Schwesig (2004), who suggested that OTs are more likely to bind to fine particles associated with higher organic carbon content, as humic acids readily form complexes with OTs.

\section{Dredged material}

Despite the strict regulations, organotins are still present in the port sediments in both Gdańsk and Gdynia. They were also recorded at both disposal sites, though without phenyltins ( $<$ LOD). 
Table 3 Recorded TBT concentrations in sediments from different ports and marinas around the world

\begin{tabular}{|c|c|c|c|c|}
\hline Location & Date of sampling & $\begin{array}{l}\text { Sediment } \\
\text { layer }[\mathrm{cm}]\end{array}$ & 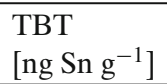 & References \\
\hline $\begin{array}{l}\text { Baltic and North Sea } \\
\text { marinas, Germany }\end{array}$ & 1997-1998 & - & $33-6,970$ & Biselli et al. (2000) \\
\hline $\begin{array}{l}\text { Stockholm harbour } \\
\text { and marinas, Sweden }\end{array}$ & 2007 & $0-2$ & $27-533$ & Eklund et al. (2010) \\
\hline Barcelona harbour, Spain & 2002 & $0-5$ & $98-4,702$ & Díez et al. (2006) \\
\hline $\begin{array}{l}\text { Ports and marinas along } \\
\text { the French Mediterranean coast }\end{array}$ & September 2004 & $0-10$ & $37-4,402$ & Cassi et al. (2008) \\
\hline $\begin{array}{l}\text { Venice Lagoon, Italy } \\
\text { (marinas, harbours and dockyards) }\end{array}$ & Late spring-summer 2003 & $0-2$ & $43-39,300$ & Berto et al. (2007) \\
\hline Ports in Kochi and Mumbai, India & 2000-2002 & - & $2-6,894$ & Bhosle et al. (2006) \\
\hline Otsuchi Bay (shipyard), Japan & 2005 & - & $8-5,740$ & Harino et al. (2007) \\
\hline $\begin{array}{l}\text { International and fishing ports } \\
\text { along the Taiwanese coast }\end{array}$ & 2001-2004 & - & $1-3,505$ & Lee et al. (2006) \\
\hline $\begin{array}{l}\text { Commercial marina in south-east } \\
\text { Queensland, Australia }\end{array}$ & - & $0-20$ & $90-3,587$ & Burton et al. (2005) \\
\hline \multicolumn{5}{|l|}{ Baltic ports, Poland } \\
\hline Port of Gdañsk & November 2008 & $0-5$ & $13-15,780$ & This work \\
\hline Port of Gdynia & & & $8-1,910$ & \\
\hline
\end{tabular}

Tributyltin contents were higher at the stations at the Gdynia disposal site (max. 84 ng Sn $\mathrm{g}^{-1}$ d.w.) than at those of the Port of Gdańsk (max. $7 \mathrm{ng} \mathrm{Sn}$ $\mathrm{g}^{-1}$ d.w.). The recent TBT input into both disposal sites, as indicated by BDI levels less than 1 for these sediments, is worth noting.

The results obtained by researchers in different parts of the world (Table 3) also indicate that the problem of organotin contamination in ports still persists, despite the restrictions. In comparison with the concentrations of TBT recorded in sediments from other ports and marinas, the results of this work place the station Ship Repair Yard 'Remontowa' in the Port of Gdańsk among the high polluted ones that in the Port of Gdynia among the least polluted.

Sediments in shipyards, marinas, ports and shipping routes are the main repositories of organotin compounds. Additionally, to guarantee safe navigation, dredging and disposal of sediments at sea are necessary. This activity in turn enhances a chance of OT remobilization from sediments to the water phase and poses a risk to marine environment. As far as regulations are concerned, according to the HELCOM Guidelines (2007) for the disposal of dredged spoil, determination of OTs in dredged material may be required only on the basis of local information regarding sources of contamination. At present in Polish regulations there are no concentration limits for organotins in dredged materials (PL Reg. 2002). This way, several dozen thousand tons of organotincontaminated sediments are still dredged and discharged at sea each year (disposal sites) in an uncontrolled manner.

Even though the input of new OTs has been minimized and declining trends in sediments have been observed in various countries, these compounds in ports and marinas should be still monitored (Cassi et al. 2008; Díez et al. 2002; HELCOM 2010). Moreover, as long as there are no limits of organotin contamination in dredged material for disposal at sea, the IMO ban may not be enough to prevent the damage to the marine environment.

\section{Summary}

This study assesses the butyltin and phenyltin contamination of the sediments in two Polish seaports, located on the coast of the Gulf of Gdańsk, which play an important role in international maritime transport and amongst European ship repair yards. Total concentrations of organotin compounds in sediments were very different depending on the sampling location and at some 
of these stations were very high. Tributyltin and its degradation products were the predominant compounds in the sediments examined and a recent tributyltin input was stated. Phenyltins were present mainly in the shipyard sediments but they were of minor importance in the sum of organotins. It is reasonable to assume that concentrations of organotin compounds were even higher just after the total ban came into force, because of the intensified removal of old antifouling paints from ships' hulls before 2008. In general, the Port of Gdańsk seems to be more contaminated by organotin compounds than the Port of Gdynia. By contrast, the dumping site in Gdańsk is less contaminated than that in Gdynia.

Correlations between organotin concentrations in sediments and environmental parameters were significant but not very high. However, seaports are quite special areas, unsuitable for studying this kind of relationship.

Despite the many recommendations, regulations and eventually the implementation of the total ban, organotin compounds are still present in high concentration in the studied port sediments. It has to be emphasized that dredged material from the ports is routinely discharged into the sea at disposal sites of the Gulf of Gdańsk without any monitoring of sediments for organotin compounds, and this activity poses a significant threat to marine life in the southern Baltic Sea. Only the regulations imposed by local authorities concerning the limits of organotin contamination for dredged material may complete the task of the IMO ban and protect the marine environment.

Acknowledgements This work was financed by the Polish-Italian Joint Research Project for 2007-2009 under the agreement on scientific cooperation between the Polish Academy of Sciences and the National Research Council of Italy (Project No. 11) and also by the Ministry of Science and Higher Education of Poland (Decision No. 190/ N-WŁOCHY/2008/0) and the statutory programme of IO PAS.

We are grateful to the Maritime Office in Gdynia for their cooperation. We express our appreciation to Dr. Jan Warzocha of the Sea Fisheries Institute in Gdynia for his help in collecting the sediment samples, and we would also like to thank Dr. Seta Noventa of the University of Venice for her technical assistance with analytical issues. Finally, we express our gratitude to Dr. Barbara Radke of the University of Gdańsk for her help with sediment grain size determination and to Dr. Ludwik Lubecki from the
Institute of Oceanology in Sopot for the organic carbon analysis and his invaluable assistance at different stages of this work.

Open Access This article is distributed under the terms of the Creative Commons Attribution Noncommercial License which permits any noncommercial use, distribution, and reproduction in any medium, provided the original author(s) and source are credited.

\section{References}

Alzieu, C. (1998). Tributyltin: Case study of a chronic contaminant in the coastal environment. Ocean and Coastal Management, 40(1), 23-36.

Berg, M., Arnold, C. G., Müller, S. R., Mühlemann, J., \& Schwarzenbach, R. P. (2001). Sorption and desorption behavior of organotin compounds in sediment-pore water systems. Environmental Science \& Technology, 35(15), 3151-3157.

Berto, D., Giani, M., Boscolo, R., Covelli, S., Giovanardi, O., Massironi, M., et al. (2007). Organotins (TBT and DBT) in water, sediments, and gastropods of the southern Venice lagoon (Italy). Marine Pollution Bulletin, 55(10-12), 425-435.

Bhosle, N. B., Garg, A., Harji, R., Jadhav, S., Sawant, S. S., \& Krishnamurthy, V., et al. (2006). Butyltins in the sediments of Kochi and Mumbai harbours, west coast of India. Environment International, 32(2), 252-258.

Biselli, S., Bester, K., Hühnerfuss, H., \& Fent, K. (2000). Concentrations of the antifouling compound Irgarol 1051 and of organotins in water and sediments of German North and Baltic Sea marinas. Marine Pollution Bulletin, 40(3), 233-243.

Bortoli, A., Troncon, A., Dariol, S., Pellizzato, F., \& Pavoni, B. (2003). Butyltins and phenyltins in biota and sediments from the Lagoon of Venice. Oceanologia, 45(1), 7-23.

Burton, E. D., Phillips, I. R., \& Hawker, D. W. (2004). Sorption and desorption behavior of tributyltin with natural sediments. Environmental Science \& Technology, 38(24), 6694-6700.

Burton, E. D., Phillips, I. R., \& Hawker, D. W. (2005). Insitu partitioning of butyltin compounds in estuarine sediments. Chemosphere, 59(5), 585-592.

Cassi, R., Tolosa, I., \& de Mora, S. (2008). A survey of antifoulants in sediments from Ports and Marinas along the French Mediterranean coast. Marine Pollution Bulletin, 56(11), 1943-1948.

Champ, M. A. (2000). A review of organotin regulatory strategies, pending actions, related costs and benefits. The Science of the Total Environment, 258(1-2), 21-71.

Díez, S., Ábalos, M., \& Bayona, J. M. (2002). Organotin contamination in sediments from the Western Mediterranean enclosures following 10 years of TBT regulation. Water Research, 36(4), 905-918.

Díez, S., Jover, E., Albaigés, J., \& Bayona, J. M. (2006). Occurrence and degradation of butyltins and 
wastewater marker compounds in sediments from Barcelona harbor, Spain. Environment International, 32(7), 858-865.

Eklund, B., Elfström, M., Gallego, I., Bengtsson, B.-E., \& Breitholtz, M. (2010). Biological and chemical characterization of harbour sediments from the Stockholm area. Journal of Soils and Sediments, 10(1), 127-141.

EU (2003). Regulation (EC) No 782/2003 of the European Parliament and of the Council of 14 April 2003 on the prohibition of organotin compounds on ships. Official Journal of the European Union, L115/1, 9.5.2003.

Evans, S. M. (1999). Tributyltin pollution: The catastrophe that never happened. Marine Pollution Bulletin, 38(8), 629-636.

Falandysz, J., Brzostowski, A., Szpunar, J., \& RodriguezPereiro, I. (2002). Butyltins in sediments and threespined stickleback (Gasterosteus aculleatus) from the marinas of the Gulf of Gdańsk, Baltic Sea. Journal of Environmental Science and Health, Part A, 37(3), 353-363.

Falandysz, J., Albanis, T., Bachmann, J., Bettinetti, R., Bochentin, I., Boti, V., et al. (2006). Some chemical contaminant of surface sediments at the Baltic Sea coastal region with special emphasis on androgenic and anti-androgenic compounds. Journal of Environmental Science and Health, Part A, 41(10), 2127-2162.

Fent, K. (1996). Ecotoxicology of organotin compounds. Critical Reviews in Toxicology, 26(1), 1-117.

Gaudette, H. E., Flight, W. R., Toner, L., \& Folger, D. W. (1974). An inexpensive titration method for the determination of organic carbon in recent sediments. Journal of Sedimentary Petrology, 44, 249-253.

Gipperth, L. (2009). The legal design of the international and European Union ban on tributyltin antifouling paint: Direct and indirect effects. Journal of Environmental Management, 90(S1), S86-S95.

Harino, H., Yamamoto, Y., Eguchi, S., Kawai, S., Kurokawa, Y., Arai, T., et al. (2007). Concentrations of antifouling biocides in sediment and mussel samples collected from Otsuchi Bay, Japan. Archives of Environmental Contamination and Toxicology, 52(2), $179-188$.

HELCOM (2007). Guidelines for the disposal of dredged material at sea-adopted in June 2007and Form for reporting of dredged material at sea-approved by HELCOM MONAS 9 in October 2006. http://www.helcom.fi/stc/files/ Guidelines/GuidelinesDredgedMaterial.pdf.

HELCOM (2009). Hazardous substances of specific concern to the Baltic Sea-Final report of the HAZARDOUS project, Baltic Sea Environment Proceedings No. 119. http://www.helcom.fi/stc/files/ Publications/Proceedings/bsep119.pdf.

HELCOM (2010). Hazardous substances in the Baltic Sea. An integrated thematic assessment of hazardous substances in the Baltic Sea. Baltic Sea Environment Proceedings No. 120B. http://www.helcom. fi/stc/files/Publications/Proceedings/bsep120B.pdf.
Hoch, M. (2001). Organotin compounds in the environment-an overview. Applied Geochemistry, 16(7-8), 719-743.

Hoch, M., \& Schwesig, D. (2004). Parameters controlling the partitioning of tributyltin (TBT) in aquatic systems. Applied Geochemistry, 19(3), 323-334.

IMO (2001). International convention on the control of harmful anti-fouling systems on ships. International Maritime Organization. http://www.imo.org.

Lee, C.-C., Hsieh, C.-Y., \& Tien, C.-J. (2006). Factors influencing organotin distribution in different marine environmental compartments, and their potential health risk. Chemosphere, 65(4), 547-559.

Maguire, R. J. (1987). Environmental aspects of tributyltin. Applied Organometallic Chemistry, 1, 475-498.

Myślińska, E. (1998). Laboratoryjne badania gruntów. Warszawa: PWN (in Polish).

Pellizzato, F., Centanni, E., Marin, M. G., Moschino, V., \& Pavoni, B. (2004). Concentrations of organotin compounds and imposex in the gastropod Hexaplex trunculus from the Lagoon of Venice. Science of the Total Environment, 332(1-3), 89-100.

PL Reg. (2002). Dz.U.02.55.498-Rozporzadzenie Ministra Środowiska w sprawie rodzajów oraz stężeń substancji, które powoduja, że urobek jest zanieczyszczony, 16.04.2002. Polish regulationdredged materials. http://isap.sejm.gov.pl (in Polish).

PL Reg. (2006). Dz.U.06.99.692-Obwieszczenie Marszałka Sejmu Rzeczypospolitej Polskiej w sprawie ogłoszenia jednolitego tekstu ustawy o zapobieganiu zanieczyszczaniu morza przez statki, 19.05.2006. Polish regulation-prevention of pollution from ships. http://isap.sejm.gov.pl (in Polish).

Radke, B., Łęczyński, L., Wasik, A., Namieśnik, J., \& Bolałek, J. (2008a). The content of butyl- and phenyltin derivatives in the sediment from the Port of Gdańsk. Chemosphere, 73(3), 407-414.

Radke, B., Staniszewska, M., Wasik, A., Namieśnik, J., \& Bolalłek, J. (2008b). Organotin compounds in marine sediments. Polish Journal of Environmental Studies, 17(5), 643-654.

Senthilkumar, K., Duda, C. A., Villeneuve, D. L., Kannan, K., Falandysz, J., \& Giesy, J. P. (1999). Butyltin compounds in sediment and fish from the Polish coast of the Baltic Sea. Environmental Science and Pollution Research, 6(4), 200-206.

Strand, J., Jacobsen, J. A., Pedersen, B., \& Granmo, A. (2003). Butyltin compounds in sediment and molluscs from the shipping strait between Denmark and Sweden. Environmental Pollution, 124(1), $7-15$.

Szpunar, J., Falandysz, J., Schmitt, O., \& Obrebska, E. (1997). Butyltins in marine and freshwater sediments of Poland. Bulletin of Environmental Contamination and Toxicology, 58(6), 859-864.

van Reeuwijk, L. P. (2002). Procedures for soil analysis. Particle soil analysis. Technical Paper 9 (6th ed.). Wageningen: ISRIC. 